\title{
SOLUBILITY OF HELIUM AND ARGON IN LIQUID SODIUM
}

E. Veleckis, S. K. Dhar,

F. A. Cafasso, and H. M. Feder

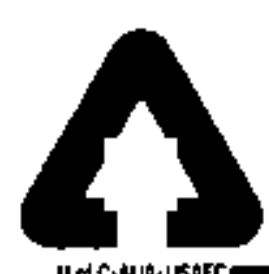

ARGONNE NATIONAL LABORATORY, ARGONNE, ILLINOIS 


\section{DISCLAIMER}

This report was prepared as an account of work sponsored by an agency of the United States Government. Neither the United States Government nor any agency Thereot, nor any of their employees, makes any warranty, express or implied, or assumes any legal liability or responsibility for the accuracy, completeness, or usefulness of any information, apparatus, product, or process disclosed, or represents that its use would not infringe privately owned rights. Reference herein to any specific commercial product, process, or service by trade name, trademark, manufacturer, or otherwise does not necessarily constitute or imply its endorsement, recommendation, or favoring by the United States Government or any agency thereof. The views and opinions of authors expressed herein do not necessarlly state or reflect those of the United States Government or any agency thereof. 


\section{DISCLAIMER}

Portions of this document may be illegible in electronic image products. Images are produced from the best available original document. 
The facilities of Argonne National Laboratory are owned by the United States Government. Uader the terma of a contract (W-3L-109-Eng-38) between the U. S. Atomic Energy Commsston, Argonne Univer sities Association and The University of Chicago, the Universiky employs the staff and optrates the Laboratory in accordance with policjes and proprams formulated, approved and reviewed by the Association.

\section{MEMBETS OF ARGONNE UNIVERSTTIES ASSOCIATION}

The Universty of Arizona Carnegit-Mellon Univer sity Cane Weatern Regerve University The University of Chita go Univerelty of Cistirarati Ilinole Intitute of Technology Univers ity of lllinois Indiant University Iown State Univeraity The University of Iawa
Kansas State University The University of Kancas Loyola Unbersity Marquette Univeratty Michigan State Undyersity The Universlty of Michigan Univeraity of Minnesola Univeraily of Mistouri Northwentern University Unjererglty of Notre Daria
The Ohto Stute Univeraity Ohio University The Penntylvania State Univeroity Purdue Univertity Saint Laule Univernity Southern Illindis University The University of Texas at Austin washington University Wayne State Undrersity The Univer sity of Wisconein

This report was prepared as in acciount of work spongored by the United States Government. Netther the United \$tates nor the United States Atomic Energy Commietion, nor any of their employee $\mathrm{g}$, nor any of the ir contractors, subcontractora, or their employees, makeo any wartanty, express or implied, or assumes any legal liability or responsibility for the accuracy, completenes or usefulnet of any information, apparatus, product or procesg disclosed, or represents that its use would not infringe privately-pwned righte.

Printed in the United State of America

Available from

National Techalcal Information Service

U.S. Department of Commerce 5285 Port Foyal Road

Springfield. Yhrginia 22151

Price: Printed Copy \$3.00; Microfiche \$0.95 


\title{
ARGONNE NATHONAL LABORATORY \\ 9700 South Cass Ayenue \\ Argonne, Illmois 60439
}

\section{SOLUBILITY OF HELIUM AND ARGON IN LIQUID SODIUM}

by

\author{
E. Veleckis, S. K. Dhar, *
}

F. A. Catasso, and H. M. Feder

Chemucal Engineering Division

Aprol 1971

This repoel wre grepared is on pecolupt of Wotk aponsored by the Unhed Stales Govemment. Nenher

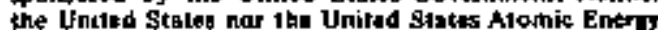
Comindsson, naf iny of thelr employees, nor any of

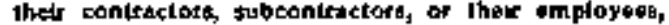
makes any wartinty, express of implied, or uspumes any lapal litbijly of teforsubdity fot the acturacy, compleseness of upefulpest at uny informalion, oppertulut. producl or process discloted, or ropinsetite thot its ust woudd nat fatiringe privotsly ouned rahts.

*DePaul Uniwersılty, Chemistry Department, Chicago, Ilinois 


\section{TABLE OF CONTENTS}

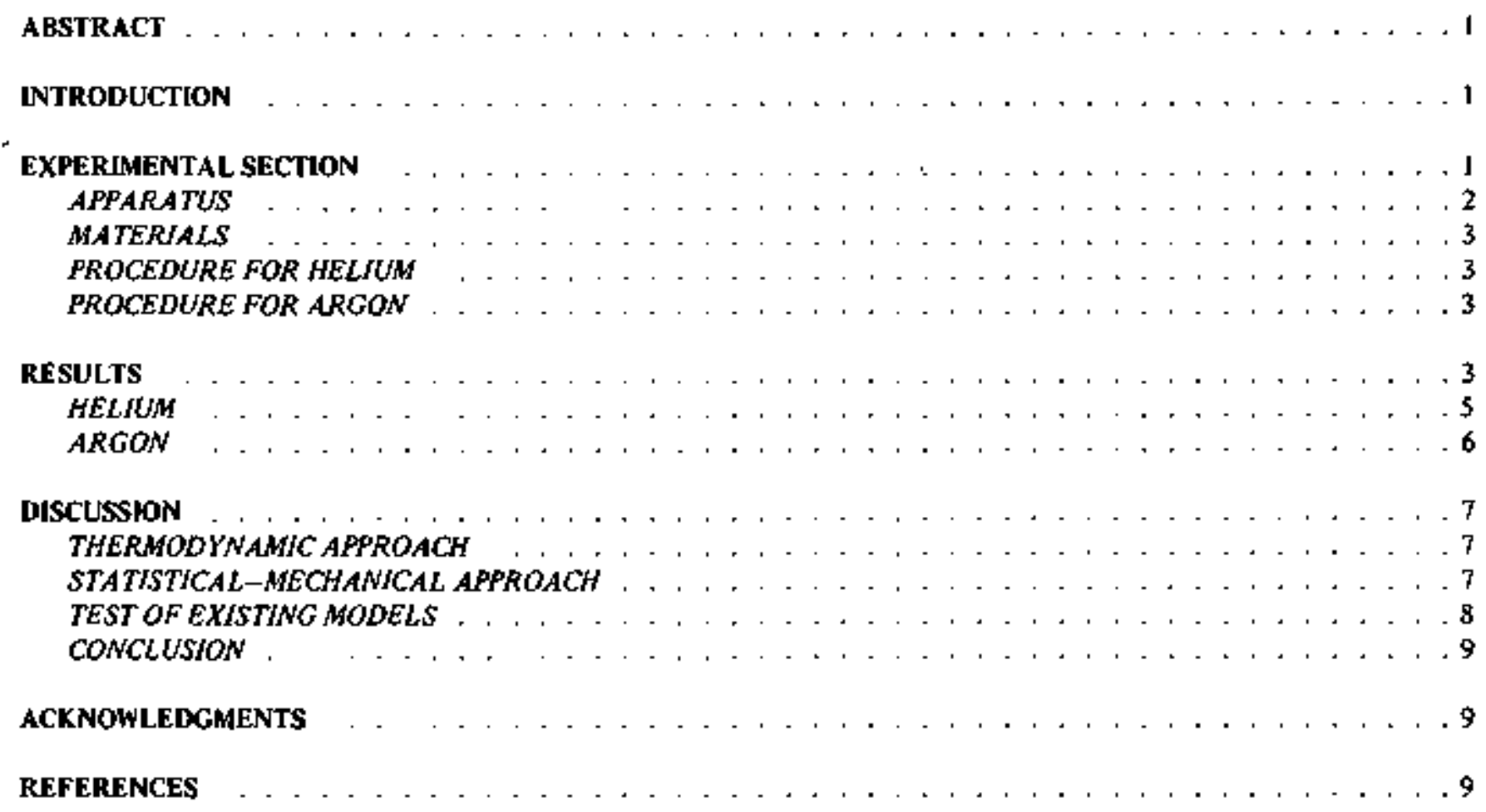




\section{LIST OF FIGURES}

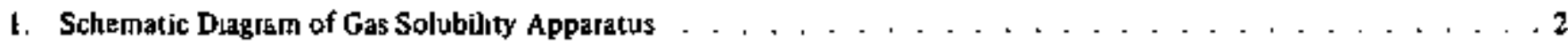

2. Pressure Dependence of the Solubibity of Hekium in Sodium at $500^{\circ} \mathrm{C} \ldots \ldots \ldots$

3. Pressure Dependence of the Solubility of Argon in Sodium at $480^{\circ} \mathrm{C} \ldots \ldots \ldots$

4. Temperature Dependence of the Solubility of Helium and Argon in Soditkm . . . . . . . . . . . . . . . 6

\section{LIST OF TABLES}

I. Dependence of the Solubility of Hehum in Liquid Sodium on Temperature and Pressute . . . . . . . . . . . . . 5

II. Dependence of Uhe Solubility of Argon in Liquid Sodium on Temperature and Pressure . . . . . . . . . . . . .

III. Ostwald Coefficients for Solutton of Helium and Argon in Liquid Sodium at 300 and $500^{\circ} \mathrm{C} \ldots \ldots$ 


\title{
SOLUBILTY OF HELIUM AND ARGON IN LIQUJD SODIUM
}

\author{
by \\ E. Veleckis, \$. K. Dhar, \\ F. A. Cafasso, and H. M. Feder
}

\begin{abstract}
The solubilities of helium and argon in liquid sodium were determined as functions of pressure and temperature. The data obeyed Henry's law to at least 9 atm. In the tenuperature range $330-550^{\circ} \mathrm{C}$. the solubilities may be represented by the foltowing line ar equations: helium, $\log \lambda=0.516 \cdot 3078 \mathrm{~T}^{\prime \prime}$; argon, $\log \lambda=1.08 \cdot 4462 \mathrm{~T}^{\circ}{ }^{\prime}$; where $\lambda$ is the Ostwald coefficient. The 95\% confidence limits of the mean ralue of $\lambda$ predicted by these equations are $\pm 4 \%$ for helium and $\pm 16 \%$ for argon. For the standard state defined as one gram-atom of ideal gas confined to a volume equal to the molat volume of sodium, the heats of solution are $14.1 \pm 0.6 \mathrm{kcal} / \mathrm{mol}$ for helium and $20.4 \pm 2.1 \mathrm{kcal} / \mathrm{mol}$ for argon. The results are compared with experimental data of others and with calculations based on existing theoretical models.
\end{abstract}

\section{INTRODUCTION}

The thermodynamics of alloy formation is sufficiently complex that especiatly simple binary systems are desirable objects of theoretical and experimentąl study. The noble gases presumably dissolve in liquid metals as neutral atomș; if so, the polarization of the dissolved atoms by the fluctuating fields of the solvent should be the only source of attractive interactions. The electronic structures of the alkali metals are better understood than those of other metals; hence the use of the alkali metals as solvents for the noble gases should simplify the evaluation of these polariza. tion forces. The alkali metal-noble gas solutions, therefore, constitute a class of especially simple binary alloys worthy of study. Measurement of the solubilites of noble gases in liquid alkali metals affords a convenient method of evaluating the thermodynamics of alloy formation.

Measurements of the solubility of noble geses in liquid metals, or theoretical discussions thertoff, are sparse. Epstein [I] calculated the solubility of helium in sodium using Hildebrand's solubility parameters. Mctsillan [2] predicted the solubility of xenon in liquid bismuth, which was subsequently measured by Eshaya and Kenney [3], Milra [4], and Hewitt, Lacey and Lyall [5] . Johnson and Shultleworth [6] and Johnson [?] measured the solubility of krypton in liquid Pb, Sn, $\mathbf{A g}, \mathrm{Cd}$, and In and attempted to rationalize their results. The only data reported on the solubility af noble gases in liquid alkali metals are those by Mitra [4], who measured the solubility of xenon in sodium; by Slotnick, Kape]ner, and Cleary [8], who measured the solubility of helium in liquid lithium and potassium; and by Thormeier [9], who measured the solubility of helium and argon in liquid sodium concurrently with the present study. Except for an inconclusive test in the Li-He system [8], the validity of Henry's law had not been examined for noble gas-metal systems prior to this work. Departures from Henry's law at moderate pressures were not expected; however, to support the presumplion of a solution as single, neutral atoms, a conclusive test of Henry's law was deemed necessary.

In the present work, attention was focused on the temperature and pressure varialions of the solubility of helium and argon in liquid sodium. These systems were of interest for the reasons already given; in addition, helizm and argon are generally used as cover gases in liquidsodium-cooted nuclear reactors, and information on their solubililies in sodium is needed by reactor designers.

\section{EXPERIMENTAL SECTION}

The equilibration and separation technique used was adepted from Grimes, Smith, and Watson [10], who had applied it to the determination of the solubility of noble gases in fused salts. In the present work, liquid sodium was saturated with the gas whose solubility was to be measured at a preselected temperature and pressure. The saturated 
sodjum was transtesred to another container, where the solution was stripped of the dissolved species by sparging. The desired component of the resulting gas mixture was concentrated by selective adsorplion and guantitatively assayed. This procedure incorporates special features which assure adequate equilibration, complete separation, and quantitalive analysis, even though the expected gas solu. bilities are very small. These features include (I) means for removing suspended solid particles (which may capture small bubbles) from the liguid to be saturated, (2) pro. longet bubbling of the saturating gas through the liguid. (3) a prolonged quiescenl period to promote the coales. cence and escape of gas bubbles, (4) very slow transfer of a portion of the saturated liquid via a bottom outlet to avoid the inclusion of liquid from the vicinity of certain surlaces, * (5) a prolonged sparging period to promote the stripping of the dissolved species, and (6) a procedure for distinguishing the stripped gas from extraneous sources of the same material

\section{APPARATUS}

Figure 1 is a schematic diagram of the appatalus used. Three cylindrical vessels (4-1/2-in. diameler, 16 in. high) fabricaled from Type 316 stainless steel were inler

FThe sodium-Bas interfaces may be entiched in the saturating eas by adsorption. (Set Rets. 3,6, and 3.) connected by heated $1 / 4$ in. sodium transfer lines equipped with needle valves. In vessel A ("purifier"), filtration was carried out periodically as a precaution against the accumulation of solid sodium oxide particles from air inleakage. Saturating gas was bubbled through the liquid contained in vessel B ("saturator") via a coiled tube with sixty 3/16-in. perforations directed toward the bottom of the vessel. In vessel C ("stripper"), the stripping gas was introduced through a Micto Metallic Corp. 10-cm stainless steel dispersion disc having a $5 \cdot \mu$ mean pore size. The volume of sodium in this vessel was calculated from its geometry and the sodium level. The level was measured to the nearest $0.5 \mathrm{~cm}$ with a Mine Safety Appliances Corp. liquid-level probe.

The three vessels were heated with 20-in.-high Marshall Products Co. split-iype electric furnaces. Temperature was measured in each vessel with a Chromel-Alumel thermocouple in a thermowell.

Separate gas-circulation loops made of 1/4-in. Type 304 stainless steel tubing were connected to the saturator and to the stripper. Each Joop contained a diaphragm pump (Lapp Pulsareeder, Model CP-1) designed for pressures up to $15 \mathrm{~atm}$, a flowmeter (Hastings Mass Flowmeter, Model LF), and a Bourdon pressure gauge. Air-cooled condensers located just above each vessel prevented sodium vapor from entering the gas-circulation systems. The condensers were periodically heated to free them of sodium. [n these loops, all valves exposed to sodium had Stellite seats; those in less critical positions had Teflon seats.

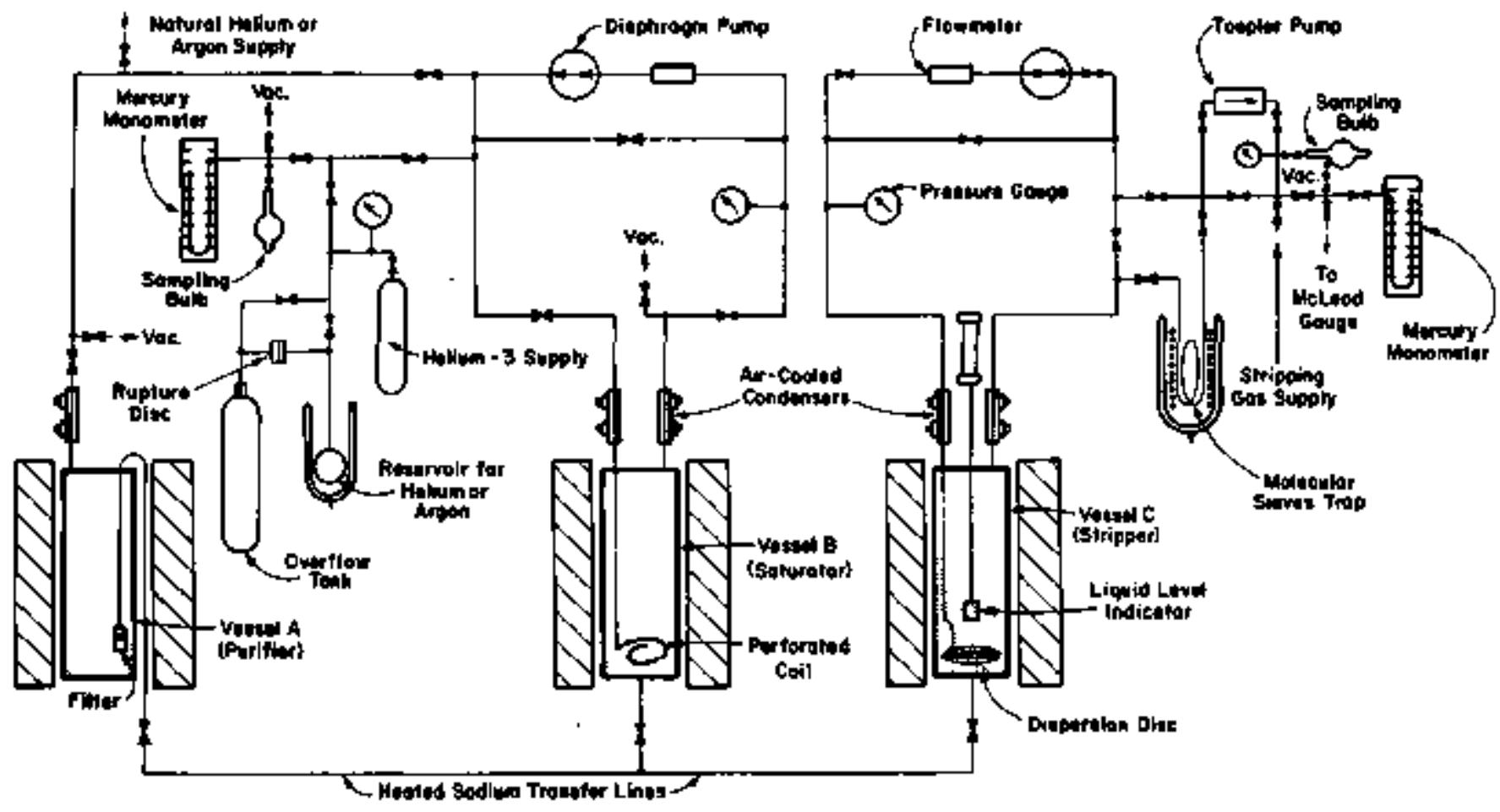

Fip. 1. Sthematic Diatram of Gas Solubiliy apparatus. ANL Nog. No. 308.2319. 


\section{MATERIALS}

Helum-3 (99 5\%) was purchased from the Mound Lab. oratory, Marmstburg, Oho, and ultrahıgh-purity (99 999\%) natural heluum from the Matheson Company, an tsotope mixture of these $\left(\sim 30 \%{ }^{3} \mathrm{He}\right.$ ) was prepared by condensung appropriate amounts of each on aclirated char. coal (Barnebey-Cheney Type 513) cooled to $4^{\circ} \mathrm{K}$ Ultrahigh-purity ( 9999 \% Matheson Company, it contained no detectable heluum Reactor-grade sodum was purfited in situ by periodic transfers of sodum (heated to $500^{\circ} \mathrm{C}$ ) 10 the purfier, where it was cooled to $150^{\circ} \mathrm{C}$ and passed through a porous metal fitter to remove insolubles At $150^{\circ} \mathrm{C}$ the solubility of oxygen (the main impuri1y) is $\sim 2 \mathrm{ppm}$ [II]

\section{PROCEDURE FOR HELIUM}

Approxinately 25 liters of liquid sodium in the sulurator was heated to and mantaned at the desired lemperature, and the iso1opic helium mixlure was pumped through it al a rate of 1 Jiter/mun for $2 \mathrm{hr}$ Pumping was then stopped, and the soduum was left undisturbed overnight Throughout the period, the saturator lemperature was mantauned constant and the pressure (predetermined by the quantuty of gas in the saturator loop) was measured The aeedle valyes in the sodum transfer line between the saturator and stripper were then slightly opented untul $\sim 2$ liters of sodium were transferred into the closed, evacuated stripper Durung this persod of $\sim 5$ mun, the helumm pressure in the saturator was manntanned at its initial value by the admission of additional isotopic helium muxture The sodum in the sirupper was cooled to $\sim 130^{\circ} \mathrm{C}$ and stripped of the dissolved helium by continuously pumpung $\mathrm{l}$ liter of argon at atmospheric pressure through the dspersion disc at $750 \mathrm{~cm}^{3} / \mathrm{mun}$ for $2 \mathrm{hr}$ When the stripping was complete, the volume of sodjum that had been transtetred was measured

The gas muxture in the strupper loop generally contaned 001 to $015 \%$ helium To enhance the aceuracy of analyss, It was desirable to concentrate the heluum Thus was done by Toepler-pumpung the mixture through ligud-nitrogen. cooled Molecular Sreves (Linde Company Type 5A) into a samplung bulb of known wolume In this process, the argon was nearly quantitatively and seleclively retanned on the Sieves, and the final helnum concentration was at least $95 \%$ Tests of the recovery procedure with known quantitses of helumm indicated that recovery of $04 \mathrm{~cm}^{3}$-atm or more was nearly quantilatuve With smaller quantities, recovernes decreased, $€ \mathrm{~g}$, with $004 \mathrm{~cm}^{3} \cdot \mathrm{atm}$, the recovery was 65 \% A calibration curve of percent recovery versus quanlity of heleum was obtanned and applied to the analytreal data

The concentration of the helium isotopes was determined by mass spectrometry The function of the added ${ }^{3} \mathrm{He}$ was to distinguish between the helium oblanned on exsolution from sodsum and any trarnp $\left({ }^{4} \mathrm{He}\right.$ ) helsum Any decrease in the ${ }^{3} \mathrm{He}$ relalive concentration would have been attributed to dLution by natural helium, and an appropriate correction would have been made, no such correction was ever nectessary

\section{PROCEDURE FOR ARCON}

Natural argon was the splute gas, and helium was used for sparging The resulting helium-argon muxture contaned from $5 \times 10^{4}$ to $2 \times 10^{2} \%$ argon The argon concentraton was encreased by pumping the muxture through a controlled leak unto a liquid-nitrogen-cooled Molecular Sieves Type $5 \mathrm{~A}$ trap The trap was healed to $300^{\circ} \mathrm{C}$, and a measured portion of the desorbed gas was assayed for argon The assayed samples contaned from $4 \times 1 \sigma^{2}$ to $3 \%$ argon, $\sim 01 \%$ nutrogen, the balance being helium Tests of this procedure with argon-heluum muxtures of known compositions showed that, within experimenta] unceriaint1es, a quant,tative recowery of argon was achueved

The gas analysts were made with a gas chromatograph designed for an adequate separation of argon and nitrogen The column was made of 8 .ft-long, 1/4-נn dia staintess steel tubing packed with Moleculas Sieves Type 5A, operated at $0^{\circ} \mathrm{C}$, and its output was measured with a thermalconductivity detector The nutrogen was assumed to have originated from arr unleakage, and a correction was riade for the corresponding amount of argon in arr Thus correctron never exceeded $1 \%$

\section{RESULTS}

The procedures described above were followed in most expenments To establish that these procedures led to valid results, varıations were made in the preluminary experiments, $\mathrm{e}$, the tome of bubbling was varsed from $\mathrm{J} / 2$ to $3 \mathrm{hr}$, the rate of bubbling was vared from $1 / 2$ to I luter/min, the quitscent perkod was extended from over. nught to several days, and multuple sitripping was st tempted From the results of these prelımunary runs, we concluded that, with respect to the time element, the selected procedures led to the regutred degree of saturation and strippung

The experimental isothermal ptessure dependence of solubility was determined from 14 measurements at $-500^{\circ} \mathrm{C}$ for helum and from eught measurements at $-480^{\circ} \mathrm{C}$ for argon The results are shown in Figs 2 and 3, where the mole fractions of helium (corrected to exactly $500^{\circ} \mathrm{C}$ ) and of argon (corrected to exactly $480^{\circ} \mathrm{C}$ ) are plotted aganst the gas pressure The corrections were based 
on the measured isobaric temperature coefficitnts of solubility delermuned in this work The experimental points were fitted by the method of leasl squares to unconstraned linear equations $O$ n the basis of statistical F-lesls, the displacements of the lines from the orighns and therr deviations from linearity wert found to be insignuficant This can be seen in Figs 2 and 3 by the posilion of the 95\% confidence limits The solubility data, therefore, obey Hency's law to at least 9 atm pressure

The solubilites of helum and argon were measured at approximately $50^{\circ} \mathrm{C}$ intervals between 330 and $550^{\circ} \mathrm{C}$ with at least quadruplicate determinations at each temperature The itmperaiures are believed to be accurate to within $1^{\circ}$

Gas solubilities are conventionally expressed in terms of two different unils (a general review of these units appears In Ref 12) (1) Henry's-law constant, $\mathrm{K}_{\mathrm{H}_{\mathrm{r}}}$ atom fraction of solute in solution per atmosphere of gas pressure, and (2) Ostwald coefficient, $\lambda=\mathrm{C}_{\mathrm{p}} / \mathrm{C}_{\hat{\mathrm{g}}}$, the ratio of the concen. tration of the solute in the liquid phase to the concentra tion of the solute in the gaseous phase in equilibrium with it Thus, the Ostwald coefficient may be regarded as a

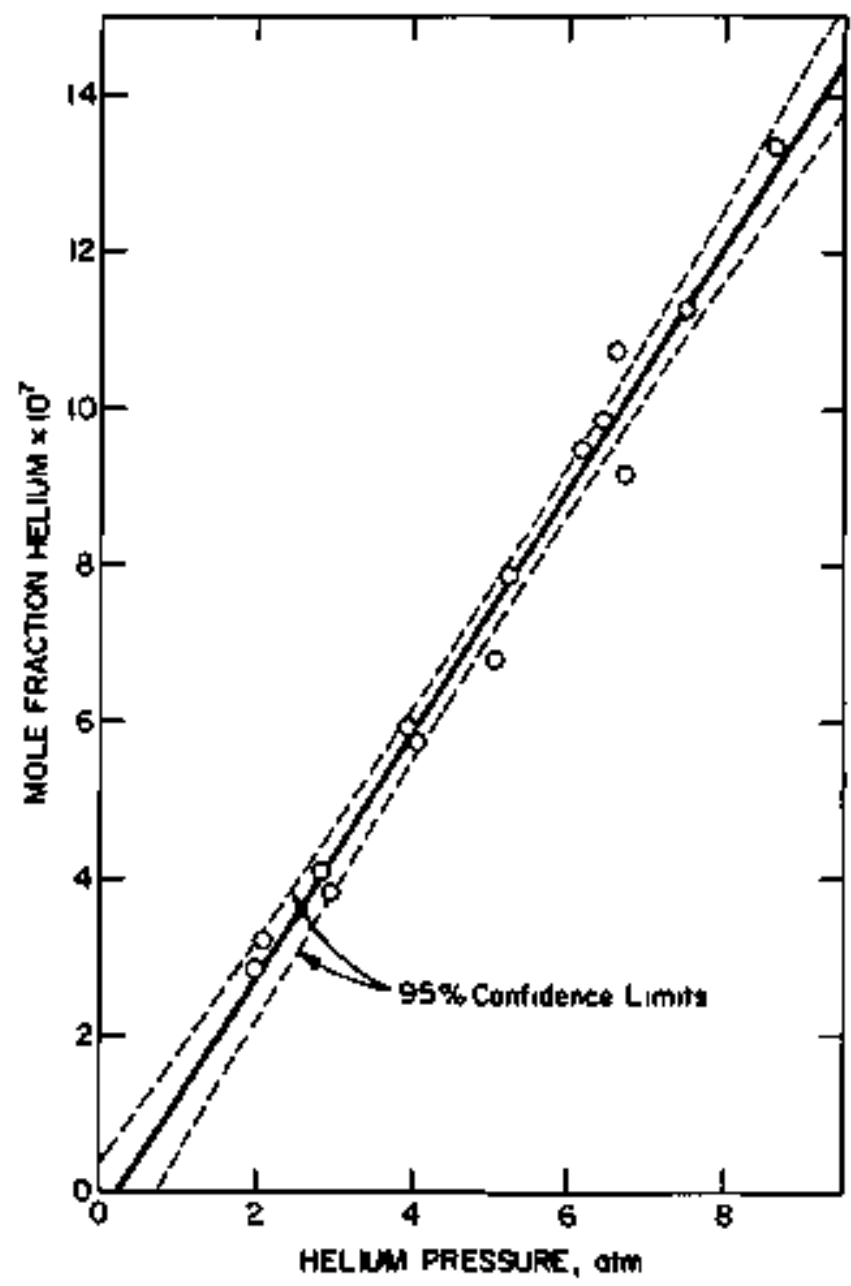

Fug 2 Fressure Dependence of the Solubality of Helsom in Sodium $11000^{\circ} \mathrm{C}$ ANL Net No 308-2320

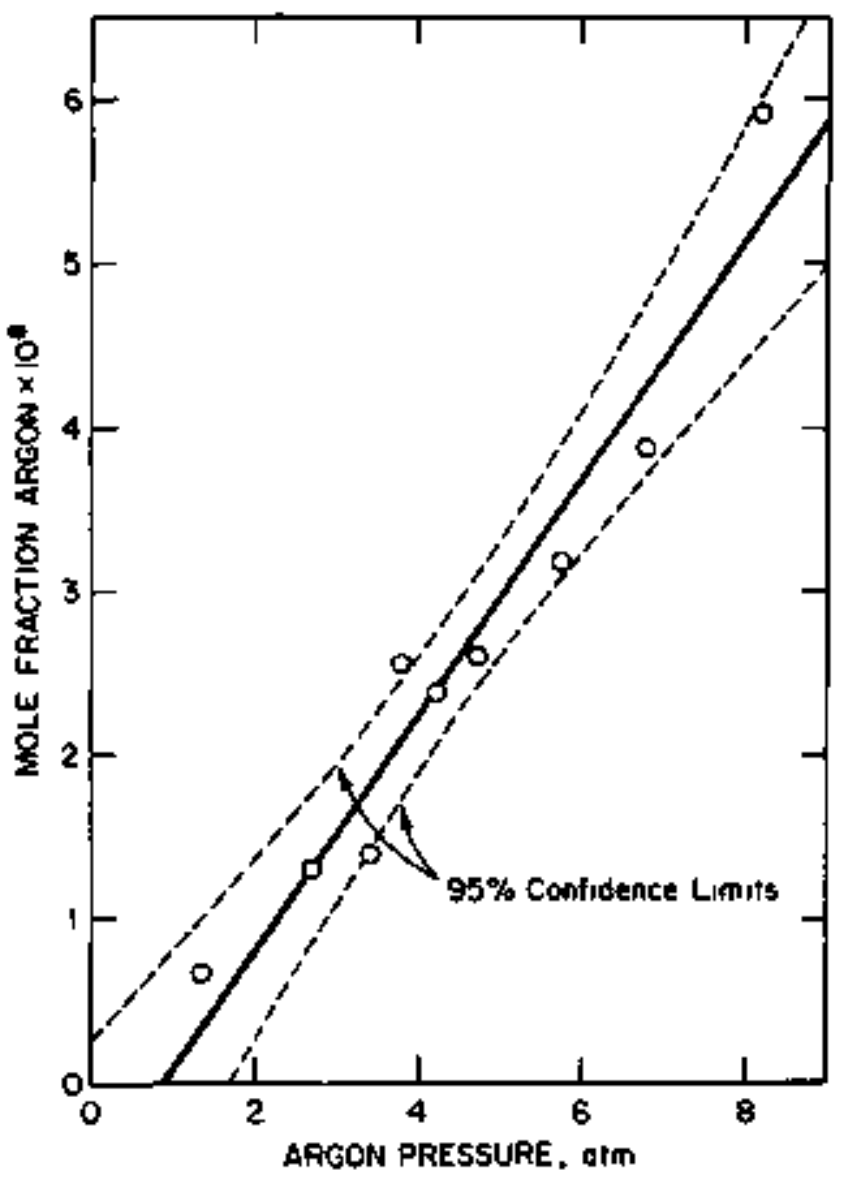

Fig 3 Pressure Dependense of the Solubility of Arton in Sodivm al 4t0 $0^{\circ} \mathrm{C}$ ANL Neg No 308.232I

partition coefficient of the soluie, one phase being a gas and the other a liquid when the gaseous phase is pure and ideal, the units $\mathrm{KH}_{\mathrm{H}}$ and $\lambda$ are related to each other by the equation $\lambda=R^{x} T d K_{H} / M$, where $R^{x}=8206 \mathrm{~cm}^{3} \cdot \mathrm{atm} / \mathrm{deg}$. mol is the gas constant, $T$ is the Kelvin temperature, $d$ is the denisity of the solvent, and $M$ its molecular weight (For Isquad sodium [13] $\mathrm{d}\left(2 / \mathrm{cm}^{3}=0950.230 \times 10^{4} \mathrm{t}=146 \mathrm{X}\right.$ $10^{6} t^{2}+564 \times 10^{12} t^{3}$, where $I$ is the temperature in ${ }^{\circ} \mathrm{C}$, and $M=2299 \mathrm{~g} / \mathrm{mol}$ ) Heats of solution may be calculated from the temperature coefficients of solubulity by the relations

$\bar{H}_{2}($ soln $, T, P)-H_{2}^{\circ}(g, T, P=J a 1 m)=+R\left[\partial \ln K_{H} / \partial(L / T)\right]$

and

$\bar{H}_{2}(\operatorname{soln}, T, P)-H_{2}^{o}\left(g, T, P=R^{\prime} T d / M\right)=R[\partial \ln \lambda / \partial(1 / T)](2)$

The heats of solution defined in Eqs 1 and 2 differ from each other with respect to the choice of the standard state of the solute The standard state used in $\mathrm{Eq} I$ is one gram. atom of ideal gas at temperature $T$ and a pressure of 1 atm, tha! used in Eq 2 is one gram-atom of ideal gas at temperature $T$ in a volume equal to the molar volume of solvent 


\section{HELIUM}

The results of 30 determinations for the solubility of helium in sodium are shown in Table $I$ and in Fig. 4. Over the range $350-550^{\circ} \mathrm{C}$, the data were fitted by the following equalions: *

$$
\log K_{H}=-3.16 \cdot 2833 \mathrm{~T}^{-1}
$$

or

$$
\log \lambda=0.516 \cdot 3078 \mathrm{~T}^{-1}
$$

A statistical analysis showed that a mean result of a prolonged series of measurements would be predicted by Eq. 3 with an uncertainty ( $95 \%$ confidence level) of less than $4 \%$. For the standard state defined as one gram-atom of ideal gas at $1 \mathrm{~atm}$, the heat of solution is $13.0 \pm$ $0.4 \mathrm{kcal} / \mathrm{mol}$; for the standard state defined as one gram-

-For technital pufposes, the solubility of natural helium expressed in wenght units is given by lap (ppb/otm He) $=5.09$. $5099 \mathrm{~T}^{\prime}$, where $\mathrm{T}$ is in degrees Rankine. atom of ideal gas in a volume equal to the molar rolume of sodiurn, the heat of solution is $14.1 \pm 0.6 \mathrm{kcal} / \mathrm{mol}$.

The helium solubility line reported by Thormeiter [9] is also shown in Fig. 4.* Al higher temperatures, the two studits agree within experimental error. Al lower temperatures, however, the results diverge. The disagreement is reflecled in the heats of solution; $16.4 \mathrm{keal} / \mathrm{mol}$, reported by Thormeier, is well outside the error limils assigned to the presently reported heal, $13.0 \pm 0.4 \mathrm{kcal} / \mathrm{mol}$. The main differences between our proceduce and Thutmeier's appear to be in the manner of equilibraling the saturating gas with the liquid and the manner of slripping and analyzing the dissolved gas. Thormeier pumped liquid sodium into a tank conlaining the saturating gas, instead of bubbling the saturating gas through the sodium. For stripping, Thormejer used evacuation rather than sparging, and the quantity of recovered gas was determined in a volumeter without compositional analysis. In the light of these differences and in the absence of an error or reproducibility analysis by

"Solubditiy resulis reporied in Ret. 9 are expreted in unils of a lechnical almosphere, ala. This unht is equal to pressure of $1 \mathrm{~kg} / \mathrm{cm}^{2}$. The appropriale conversion faclor is $1 \mathrm{alm}=1.0333 \mathrm{ata}$.

TABLE I. Dependence of the Solublitity of Helium in Liquid Sodium an Temperature and Pregsure

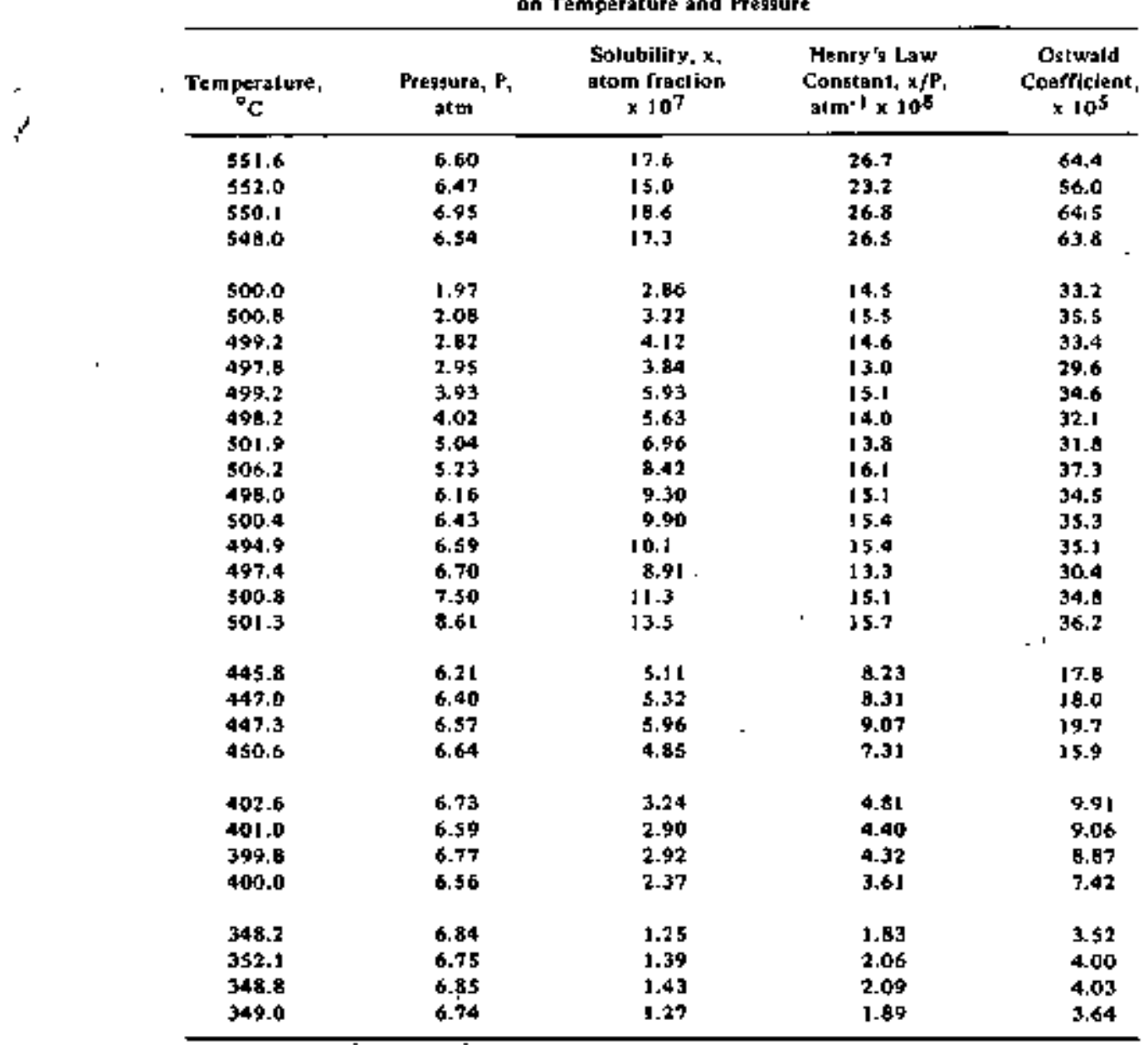




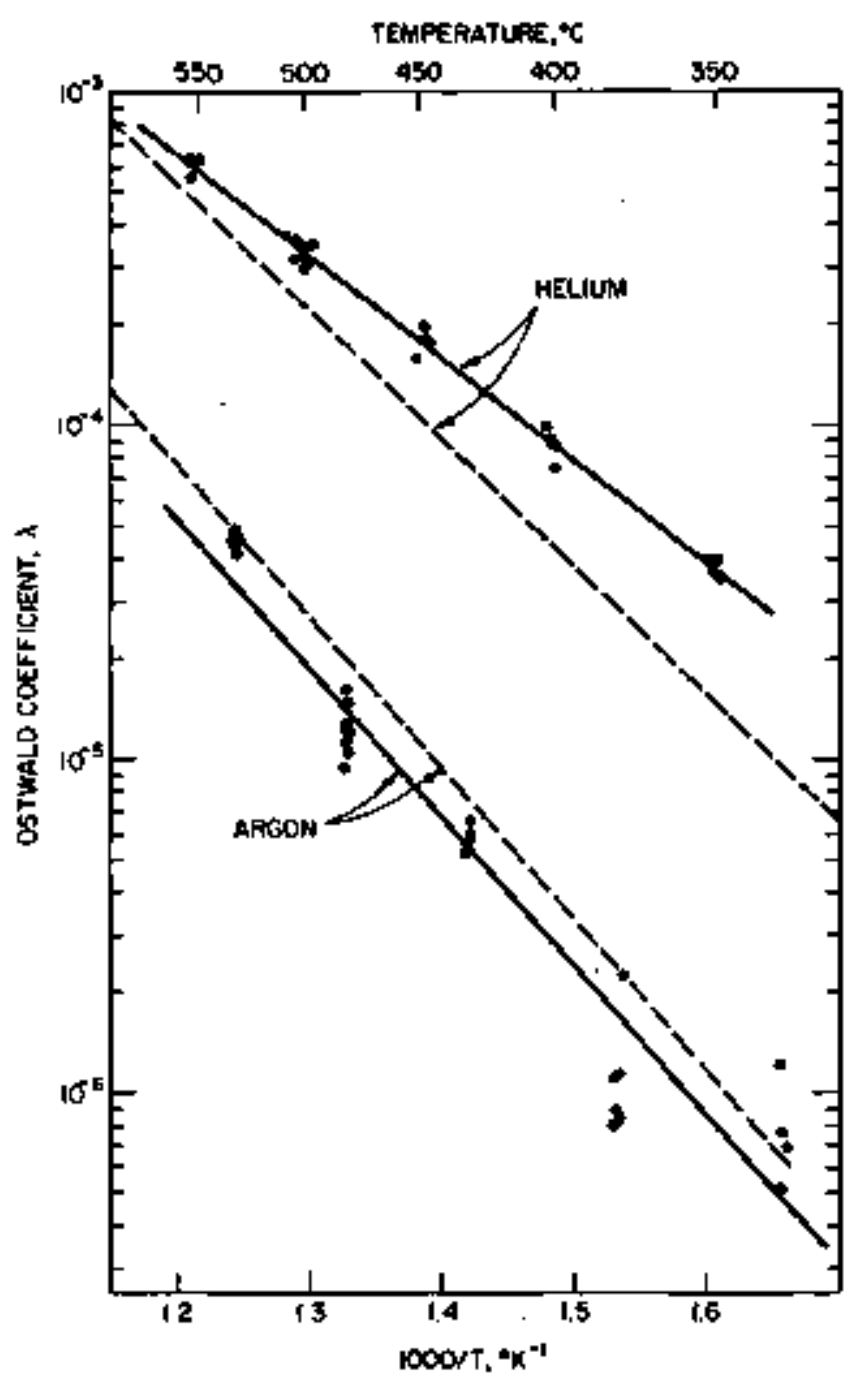

Fip- 4. Temperature Dependence of the Solubility of Helium and Argon in 5odium: -
Thormeier, it is difficult to comment further on the source of discrepancy.

\section{$A R G O N$}

The results for argon are shown in Table II and Fig. 4. Over the range $330-530^{\circ} \mathrm{C}$, the solubility data ( 30 points) were well fitted to linear equations* by the method of least squares:

$$
\log \mathrm{K}_{\mathrm{H}}=.2 .59 \cdot 422 \mathrm{IT}^{-1}
$$

or

$$
\log \lambda=\left[.08 \cdot 4462 \mathrm{~T}^{-1}\right. \text {. }
$$

The $95 \%$ confidence limits of the predicted mean values of

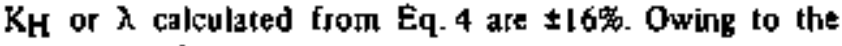
difficuity of assaying gas mixlures containing less than 5 mol o\% argon, the reproducibility of the argon results was noliceably inferior to that of the helium results.

The heat of solution of argon in sodium is $19.3 \pm 1.2 \mathrm{kcal} / \mathrm{mol}$ when the standard state of argon is taken as one gram-atom of ideal gas at $\mathbf{l} \mathbf{a t m}$, or $20.4 \pm 2.1 \mathrm{kcal}$ 'mol when the slandard state corresponds to one gram-atom of ideal gas in a volume equal to the molar volume of sodium.

Thormeier's results for the solubility of argon in sodium [9] are also shown in Fig. 4. The 16\% relative uncertainty we have assignted to our results overlaps Thormeier's solubitity line at ali temperatures, and his reported heat of solution, $20.0 \mathrm{kcal} / \mathrm{mol}$, agrees well with the value $19.3 \pm 2.1 \mathrm{kcal} / \mathrm{mol}$ from this work.

For technical purposes, the solubltty of atgon expragsed in

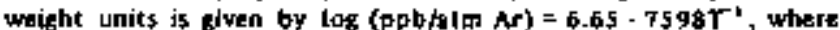
$T$ is in deprees Rankine.

TA BLE It. Dupendence of the Solubilay of Argon in Limuid Sodeum

\begin{tabular}{|c|c|c|c|c|c|c|c|c|c|}
\hline Temperalure. & $\begin{array}{c}\text { Pressure, } P \text {. } \\
\text { atm }\end{array}$ & $\begin{array}{l}\text { Solu bllwy, } x \text {. } \\
\text { atom fraci won } \\
x 10^{4}\end{array}$ & 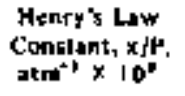 & $\begin{array}{c}\text { Osiwald } \\
\text { Conrficlent. } \\
\times 10^{4}\end{array}$ & $\begin{array}{c}\text { Tempe iature, } \\
{ }_{C}\end{array}$ & $\begin{array}{c}\text { Prossure. } 1 . \\
\text { slm }\end{array}$ & $\begin{array}{l}\text { Solubility. } 1 \text {, } \\
\text { atom fraction } \\
\times 10^{4}\end{array}$ & $\begin{array}{l}\text { Henry'\$ Las } \\
\text { cansisanl, lip. } \\
\lim ^{-1} \times 10^{4}\end{array}$ & $\begin{array}{c}\text { Ostwald } \\
\text { CoefTicien I. } \\
\times 10^{6}\end{array}$ \\
\hline 530.0 & 3.54 & 7.01 & 19.8 & 46.8 & 430.1 & 6.73 & 1.80 & 2.67 & 5.68 \\
\hline 530.5 & 3.78 & 7.41 & 19.6 & 46.7 & 430.6 & 6.78 & 2.10 & 3.10 & 6.60 \\
\hline 530.8 & 3.91 & T.35 & 18.8 & 44.5 & 431.0 & 6.80 & 1.65 & 2.47 & 5.18 \\
\hline 530.6 & 6.77 & 13.8 & 20.4 & 48.2 & 430.7 & 6.61 & 1.94 & 2.85 & 6.07 \\
\hline 530.2 & 6.19 & 13.6 & 20.0 & 47.7 & & & & & \\
\hline \multirow[t]{2}{*}{529.6} & 6.80 & 12.0 & 17.7 & 41.0 & 379,8 & 6.76 & 0.295 & 0.436 & 0.874 \\
\hline & & & & & 380.4 & 6.80 & 0.374 & 0.550 & 1.10 \\
\hline 480.6 & 1.36 & $0.6 \mathrm{J7}$ & 4.98 & 11.2 & 379.0 & 1.87 & 0.202 & 0.413 & 0.827 \\
\hline 479.6 & 2.72 & 1.29 & 4.74 & 10.7 & 379.0 & 6.84 & 0.383 & 0.560 & 1.12 \\
\hline 480.4 & $\$ .40$ & 1.41 & 4.15 & 9.37 & 380.4 & 6.44 & 0.271 & 0.396 & 0.794 \\
\hline 470.4 & 3,18 & 7.49 & 6.39 & 14.8 & 377.2 & 6.87 & 0.764 & 1.12 & 2.24 \\
\hline 480.2 & 4,27 & 2.39 & 5.66 & 12.7 & & & & & \\
\hline 479.6 & 4.71 & 2.58 & $5.4 \mathrm{H}$ & 12.3 & 330.2 & 6.67 & 0.268 & 0.402 & 0.755 \\
\hline 479.6 & 5.74 & 1.17 & 5.52 & 12.4 & 331.0 & 6.70 & D.435 & 0.649 & 1.22 \\
\hline 479.6 & 600 & 3.7? & $\$ . \$ 4$ & 12.5 & 330.4 & 6.73 & 0.186 & 0.273 & $0 . \$ 17$ \\
\hline 479,6 & d. 19 & 5.81 & 7.18 & 16.1 & $\begin{array}{l}326.8 \\
320.0\end{array}$ & $\begin{array}{l}6.80 \\
6.83\end{array}$ & $\begin{array}{l}0.250 \\
0.2 \$ 1\end{array}$ & $\begin{array}{l}0.368 \\
0.367\end{array}$ & $\begin{array}{l}0.690 \\
0.698\end{array}$ \\
\hline
\end{tabular}
on Tampitalute and tresture 


\section{DISCUSSION}

\section{THERMODYNAMIC APPROACH}

The solubility of noble gases in liquid melals may be examuned on the basus of theoretical models Consuder a binary system composed of two phases a dilute solution of $a$ noble element (2) in a solvent ( 1 ), and gaseous phase contaning only the noble element At equilibrium, the chemical potential of the noble element $w$ il be the same in both phases

$$
\mu_{2}(s o l, T, P)=\mu_{2}(g, T, P)
$$

For the chemucal potential of the noble element in the solution, one may wite

$$
\mu_{2}(\text { sol, T,P })=R^{\prime} T \ln \left(x_{2} \gamma_{3}\right)+\mu_{2}^{\circ}(\mathrm{Q}, \mathrm{T}, \mathrm{P})
$$

where $x_{2}$ is the mole fraction, $\gamma_{2}$ is the activity coefficient of the solute, and the superscript ${ }^{\circ}$ refers to a standard state consising of the pure, liquid noble element at temperature $T$ and pressure $P$ (Above the critscal temperature, this standard state is a hypothetical one) For the gas phase at the same temperature and pressure,

$$
\mu_{2}(\mathrm{~g}, \mathrm{~T}, \mathrm{P})=\mathrm{R}^{\prime} \mathrm{T} \ln \mathrm{P}+\beta \mathrm{P}+\mu_{2}^{\mathrm{a}}(\mathrm{g}, \mathrm{T}, \mathrm{I} \mathrm{atm})
$$

In Eq 7, the vorial series has been termunated at $\beta$, the second virial coefficient of the gas The chemical potenisal of the pure, liquid nobie element under its own yapor pressure, $P_{a}^{\circ}$, may be wfilten as

$$
\mu_{2}^{0}\left(\ell, T P_{2}^{o}\right)=R^{\prime} T \ln P_{7}^{\alpha}+\rho P_{2}^{\circ}+\mu_{2}^{o}(g, T, J a t m)
$$

Combination and rearrangement of Eqqs 5-8 yıld

$\ln K_{H} \equiv \ln \left(x_{2} / P\right)=\cdot \ln P_{Z}^{o}$

$$
+\left(\mathrm{P} \cdot \mathrm{P}_{2}^{o}\right)\left(\beta-\mathrm{V}_{2}^{\alpha}\right) / \mathrm{R}^{\lrcorner} \mathrm{T}-\operatorname{In} \gamma_{2}
$$

or

$\ln \lambda=\ln \left(R^{\prime} T / P_{2}^{\circ} V_{1}\right)+\left(P-P_{2}^{\circ}\right)\left(\beta-V_{2}^{\circ}\right) / R^{\prime} T-\ln \gamma_{2}$

In Eq $9, \mu_{2}^{0}\left(R, T, P_{2}^{o}\right)-\mu_{2}^{0}(R, T, P)$ was taken to be equal to $V_{2}^{0}\left(P_{2}^{0}-P\right)$, where $V_{2}^{0}$ is the molar volume of the pure, liquid noble element

One method of estimating the activity coefficent of the solute is through the use of Huldebtand's solubulity parameters [14]

$\ln \gamma_{2}=\ln \left(V_{2}^{\circ} / V_{1}\right)+\left(1 \cdot V_{2}^{\circ} / V_{1}\right)+V_{2}^{a}\left(\delta_{2}-\delta_{1}\right)^{2} / R T$

With this estimnate,

$$
\begin{aligned}
\ln \lambda & =\ln \left(R^{\prime} T / P_{2}^{o} v_{2}^{o}\right) \cdot V_{2}^{o}\left(\delta_{2}+\delta_{1} j^{2} / R T\right. \\
& +\left(P \cdot P_{2}^{o}\right)\left(\beta \cdot V_{2}^{o}\right) R^{\prime} T-\left(1-V_{2}^{o} / V_{1}\right)
\end{aligned}
$$

This method of estumation was used by Epstein [1] for helum in sodumm and by Mitra [4] tor xenon sn bismuth Epsten's predicled value al $482^{\circ} \mathrm{C}, \mathrm{K}_{\mathrm{H}}=15 \times 1 \mathrm{~J}^{10}$ $a^{-1} m^{-1}$, is lower than our measured solubiluty by a factor of $10^{3}$ Mitra's value at $500^{\circ} \mathrm{C}, \mathrm{KH}=13 \times 1 \sigma^{10} \mathrm{~atm}^{-1}$, does nol disagree with the best experumental result[5], $<2 \times 10^{10} \mathrm{~atm}^{-1}$

\section{STATISTICAL-MECHANICAL APPROACH}

The problem may also be examined by consudering the statistical mechanics of the interactugn between the solvent and the solute atoms, the latter being treated as a quasi-gas moving freely in the volume occupied by the solution Under these conditions, the molar chemical polential of the solute may be expressed by the equation (see Ref 15 , p 373)

$$
\mu_{2}\left(\operatorname{sol}_{1} T P\right)=\mathrm{N}_{0} X_{2}+P \bar{V}_{2}-\mathrm{RT} \ln \phi_{2}(\mathrm{~T})+\mathrm{RT} \ln \mathrm{C}_{\mathrm{sol}} \text {. }
$$

where $x_{2}$ is the molecular potental energy of a solute atom, relative to the stale of infinste separation, $\nabla_{2}$ is the partial molar volume of the solute, $\phi_{2}(T)$ is the partition function of the solute, uncluding both translational and internal degrees of freedom, and $\mathrm{C}_{5 \mathrm{OO}}$ is the concentration of solute atoms in solution

Simularly, for the gaseous phase, the molar chemucal potential may be written as

$$
\mu_{2}(\mathrm{~g}, \mathrm{~T}, \mathrm{P})=-\mathrm{RT} \ln \phi_{2}(\mathrm{~T})+\mathrm{RT} \ln \mathrm{C}_{\mathrm{g}}
$$

whese $C_{\mathrm{g}}$ is the concentration of noble element atoms and It is assumed that the translational and internal degrees of freedom of the solute are unaffected by the solution process

Equalions 5,12 , and 13 may be combined to yeeld

$$
R T \ln \lambda \equiv R T \ln \left(C_{\text {sol }} / C_{g}\right)=N_{0} X_{2} \cdot P \bar{V}_{2}
$$

The quantily $\left(-N_{0} X_{2}+P \bar{V}_{2}\right)$ represents the reversible work of adding one mole of noble gas to the pure solvent to form an infinitely dulute solution For solution of gases in likquids, Uhlig [16] proposed an atomistic model which is equivalent to replacement of the quentsty $\left(-\mathrm{N}_{0} \chi_{2}+\mathrm{PV}_{2}\right)$ by the sum of two letms $\mu_{C}$, the reversible work required to make a mole of internal cavitues, of a suze correspondang to the molar volume of the solute, int the body of the solvent, and $\mu_{1}$, the reversible work correspondung to the interaction of the solute atoms with the surrounding solvent Stveral 
methods have been proposed for evaluating these terms Uhlig considered $\mu_{\mathrm{c}}$ to be equal to the work done to make internal surfaces against the solvent's macroscopic surface tensoon, he did not attempt to evaluate the jnteractıon term independently McMulan [2], estimated the energy of cavity formation to be the product of the surface area of the cavity and a microscopic surface energy The latter was estumated as one.fourth of the energy of vaporization per unit area occupred by solvent aloms in the normal surface The energy of interaction was calculated with the London equation for the dispersion forces between the solute atom and only the nearest-nenghbor solvent atoms Johnson and Shuttleworth [6] proposed a nodel simular to Uhilig's, except that the translational modes of the solute atoms are supplemented by vibratıonal ones, $1 \mathrm{e},\left(-\mathbf{N}_{0} X_{2}+P \nabla_{2}\right)=$ $\mu_{c}+\mu_{1}+\mu_{y_{3} b}$ They considered $\mu_{c}$ to be given by the surface area of a solute atom multipled by the surface energy of the solvent, approximated (by a comparison with surface adsorptıon potentuals) $\mu_{\text {, to }}$ be constant at $-5 \mathrm{kca} / \mathrm{mol}$, and estumated the vibrational contribution, $\mu_{v 1 b}=H_{v b b}-T S_{v i b}$, of the solute by taking $H_{v i b}$ and $S_{v i b}$ to be equal to the enthalpy and entropy of the solvent in addition, Johnson and Shuttleworth dxd not asstgn toqual values to the pactition function of component 2 in the gaseous and in the solution phases (see Eqs 12 and 13) Instead, for the gas, the partition function was zepresented by th transiational component, $\left(2 \pi m \mathrm{kT}^{3 / 2 / 2} / \mathrm{h}^{3}\right.$, and, for the solution phase, by the number densty of the solvent Using the Johnson and Shutlleworth approach, Slotnick et al [8] found the predicted solubilities of helium in liquid hithum and potassium to be about 600 times larger than the experumental results Piecotto [17], in a more sophusticated treatment, evaluated $\mu_{\mathcal{C}}$ as the free energy of cavity formation un a hard-sphere fludd, using methods developed by Reiss et al [t8] The interaction term, $\mu_{L}$. was evaluated in terms of an integrated form of the Lennard-Jones (12-6) potential with the Kurkwood-Nuller equation for the dispersion forces

\section{TEST OF EXISTING MODELS}

All the models capable of quantitative evaluation were tested aganst the solubuties of helıum and argon in lıguıd sodium The results are shown in Table [I]
1 In the Epstein model, the predicted solubulsty depends markedly on the value assigned to the hypothetical quan. tuty $\mathrm{P}_{2}^{\circ}$ Values of $\mathrm{P}_{2}^{\circ}$ were obtaned by extrapolation of the vapor-pressure equations from the acossible regons to the supercritical regions These equations were as follows

$$
\text { Helium [19] } \begin{aligned}
& \log P_{3}^{\infty}(31 m)=1848-7948 \mathrm{~T}^{-1}-01363 \mathrm{~T}^{-2} \\
& +4363 \mathrm{~T}^{-3},
\end{aligned}
$$

$$
\text { Argon [20] } \log P_{2}^{0}(a 1 m)=3964 \cdot 346 T^{-1}
$$

For this model, the molar volumes, $V_{\mathrm{He}}=318 \mathrm{~cm}^{3}$ and $V_{A T}^{\mathrm{a}}=242 \mathrm{~cm}^{3}$, were taken unchanged from their values at the normal bouing points Hudebrand's solubuluty parameters $\left(5_{\mathrm{He}}=0588 \mathrm{cal}^{1 / 2} \mathrm{~cm}^{-3 / 2}, \delta_{\mathrm{AT}}=756 \mathrm{cal}^{1 / 2}\right.$ $\mathrm{cm}^{-3 / 2}, \delta_{\mathrm{Na}}=2750 \mathrm{cal}^{1 / 2} \mathrm{~cm}^{-3 / 2}$ ) were estımated (see Ref 15, p 424) from the hests of vaporization at the normal bollug pounts The second witual coefficients were taken to be $1076 \mathrm{~cm}^{3} / \mathrm{mol}\left(300^{\circ} \mathrm{C}\right)$ and $1014 \mathrm{~cm}^{3} / \mathrm{mol}$ $\left(500^{\circ} \mathrm{C}\right)$ for helum $[21]$ and $1077 \mathrm{~cm}^{3} / \mathrm{mol}\left(300^{\circ} \mathrm{C}\right)$ and $1776 \mathrm{~cm}^{3} / \mathrm{mol}^{2}\left(500^{\circ} \mathrm{C}\right)$ for argon [22]

2 In McMillan's model, the interaction term was calcula. ted from

$$
\mu_{1}=Z(3 / 2)\left(a_{1} a_{2} / a_{2}^{6}\right)\left[I_{1} l_{2} /\left(I_{1}+1_{2}\right)\right] .
$$

where $a$ is the atomic polarizabulty $\left(a_{\mathrm{He}}[23]=\right.$ $0204 \times 10^{-24} \mathrm{~cm}^{3}, a_{A r}[23]=163 \times 10^{24} \mathrm{~cm}^{3}$, $a_{\mathrm{Na}}(23)=297 \times\left(\sigma^{24} \mathrm{~cm}^{3}\right), \mathrm{I}$ is the ionization potential (]$\left._{\mathrm{He}}[24]=2458\right] \mathrm{eV},\left[_{\mathrm{Ar}}[24]=15756 \mathrm{eV},[\mathrm{Na}[24]=\right.$ $5138 \mathrm{eV}), a_{1}$, is the dist3nce between the centers of the solule and solvent atoms ( ${ }^{\mathrm{Na}}-\mathrm{He} \equiv 321 \times 10^{8} \mathrm{~cm}$, ${ }^{a} \mathrm{Na}-\mathrm{Ar} \equiv 360 \times 10^{-8} \mathrm{~cm}$ ), and $\mathrm{Z}$ is the number of nearest sodium nesghbors, estimated to be $\mathbf{9 4}$ and 1 I 8 for helium and argon, respectively The cavity term, $\mu_{c}$, was calculated from $\mu_{c}=\pi a_{2}^{2} \Delta H_{j}^{V} / 4 N_{0} \sigma$, where $\Delta H_{j}^{Y}$ is the heat of vaporization of sodium $(237 \mathrm{kcal} / \mathrm{mol})$ and $\sigma$ is the cross-sectional area of a solvent atom on the surface $(\sigma \mathrm{Na} \cong$ $248 \times 10^{-16} \mathrm{~cm}^{2}$ )

3 In Johnsan and Shuttleworth's mode], the cavity term was calculated from $\mu_{C}=4 \pi a_{2}^{2} \gamma_{1}^{*}$, where $a_{2}$ is the radus of the solute atom (aHe $\cong 132 \times 10^{-4} \mathrm{~cm}, a_{\mathrm{Ar}} \cong 170 \times$ $\left.1 \sigma^{5} \mathrm{~cm}\right)$ and $\gamma_{i}^{\circ} 15$ the hypothetical surface energy of Juquid sodium at $0^{\circ} \mathrm{K}\left(220 \mathrm{erg} / \mathrm{cm}^{2}\right)$ [25] For the calcula.

\begin{tabular}{|c|c|c|c|c|}
\hline \multirow[b]{2}{*}{ Model } & \multicolumn{2}{|c|}{ Na He } & \multicolumn{2}{|c|}{$N_{n} A r$} \\
\hline & $300^{\circ} \mathrm{C}$ & $500^{\circ} \mathrm{C}$ & $300^{\circ} \mathrm{C}$ & $500^{\circ} \mathrm{C}$ \\
\hline $\begin{array}{l}\text { Epstein | | | } \\
\text { MeMillan | } 2 \text { | }\end{array}$ & $\begin{array}{l}456 \times 10^{8} \\
086\end{array}$ & $\begin{array}{l}106 \times 10^{5} \\
089\end{array}$ & $\begin{array}{c}323 \times 10^{-4} \\
31\end{array}$ & $\underbrace{}_{31} \times 10^{-3}$ \\
\hline $\begin{array}{l}\text { Shultleworth [6) } \\
\text { Pseratil ( } 17 \text { I } \\
\text { Observed (this work) }\end{array}$ & $\begin{array}{l}647 \times 10^{2} \\
136 \times 10^{2} \\
136 \times 10^{-6}\end{array}$ & $\begin{array}{l}179 \times 101 \\
278 \times 102 \\
324 \times 10^{4}\end{array}$ & $\begin{array}{l}372 \times 10^{5} \\
529 \times 10^{3} \\
198 \times 10^{7}\end{array}$ & $\begin{array}{l}290 \times 10^{4} \\
125 \times 10^{2} \\
204 \times 10^{5}\end{array}$ \\
\hline
\end{tabular}
toon of the vibrational term, the enthalpy and entropy of

TABLE III OAwald Coeffic wis for Soluicon of Halutm and Argon un Lowid Sodum a1 300 ans $300^{\circ} \mathrm{C}$ 
sod lum [26] were taken to be $416 \mathrm{kcal} / \mathrm{mol}$ and $187 \mathrm{call}$ deg-mol for $300^{\circ} \mathrm{C}$ and $557 \mathrm{kcal} / \mathrm{mol}$ and $208 \mathrm{cal} / \mathrm{deg}-\mathrm{mol}$ for $\$ 00^{\circ} \mathrm{C}$, respectively

4 The seader is refersed to Pierolti's paper [17] for delals of his model Here, the caleulaled solubululy is a sensitive function of the value selected for the bard-sphere duameter of the solvent we have selected $319 \mathrm{~A}$ for $300^{\circ} \mathrm{C}$ and $312 \mathrm{~A}$ for $500^{\circ} \mathrm{C}$ as the hard-sphere diameter of sodum, as diseussed by Ascare]l [27] The values for the alomse magnetic susceptibilities [23] required for the calculation of the Kurkwood-Muller interaction term were taken to be $X_{\mathrm{He}}=.290 \times 10^{30} \mathrm{~cm}^{3}, X_{\mathrm{Ar}}=.324 \mathrm{X}$ $10^{29} \mathrm{~cm}^{3}$, and $x \mathrm{Na}=-900 \times 10^{29} \mathrm{~cm}^{3}$

\section{CONCLUSION}

Examınation of Table III shows that Epsteun's model predicts solublittes much larger and much smaller than thase observed A major weakness of thus moxtel is the need for extrapolation of the vapor pressure of the solute to unphysical regions For helıum, in partscular, the quantum effects which dominate the vapor pressure of the liquid at low temperatures would be poorly taken into account by simple extrapolation to hygher temperatures The models proposed by Mckullan, by Johnson and Shutlleworth, and by Pierotli yeld solubulutues generally higher than those observed It is suggested that the inadequaces of these models stem primarily from the est estates of the cavilyformation term These estimates, which may be adequate for insulating solvents, seem to fal for metallic solvents $A$ theoretical treatment which specifically doals with the electronic work of cavity formation in a metallic solvent seems required Such a model has been developed in this laboratory and wil appear elsewhere [28]

\section{ACKNOWLEDGMENTS}

We wish to thank Dr Irving Johason for helpful discusslons, $R$ M Yonco, G W Reding, $R$ A Blomquist, and
M T Perm for technical assistance, and $\mathrm{Dr} M \mathrm{H}$ Barsky and A F Panek for gas-chromatographic analy ses

\section{REFERENCES}

I L F Epsteun, The Solubilaty of Hetum Gas in Laqud Sodtum, KAPL-M.LFE- 10 (Oct 30, 1951)

2 W G Molullan, Estmotes of the Solubrhty and Dif. fuston Constant of Xenont in Liquid Brsmuth LMFR-1 2 (June 1955)

3 A $M$ Eshaya and W F Kenney, Solubtithy of Xenon in Loqutd Bismtth, BNL-617 (T-J86) (Jan 1959)

4 C Mitra, Solubility of Xerion in Liqued Metals, Eng Sc D Dissertetion, Columbia University (1959)

5 G F Hewtt, J A Lacey, and E Lyall, The Deter mination of Xenon in Laqued Bismuth, J Nucl Energy 1, 167 (Mar 1960)

6 G W Johnson and R Shutlleworth, The Solubituty of Krypton in Liquad Lead, Th, and Stwer, Phal Mag 4, 957 (Aug 1959)

$7 \mathrm{G} W$ Johnson, The Solubthty of Krypton in Liqutid Cadmum and indum, bud 6,943 (July 1961)

8 H Slotnick, S M Kapelner, and R E Cleary, The Sol. ubuty of Helum in Lithum and Potassum, PWAC. 380 (Feb 24, 1965)

9 (a) K Thormeer, Sotubutty of Hetum in Laq. und Sodnum, Atomkernenerge 14, 449 (Now-Dec 1969), (b) K Thormeser, Solubulity of the Noble Gosses in Laquad Sodum. Nucl Eng Design 14. 69 (1970)

10 W R Grımes, N V Smuth, and G M Watson, Solwbulty of Noble Gases in Molten Fuorides I in
Mextures of $\mathrm{NaF}_{2} \mathrm{ZrF}_{4}$ (53-47 mole\%) and NaF$\mathrm{ZrF}_{4} \cdot U F_{4}$ (50-46-4mole\%), I Phys Chem 62, 862 (Juty 1958)

1) V J Rulkauskas, Determination of the Solubilty of Oxygen in Sodum by Vacurum Distatation, LA.3879 (July 1S, 1968)

12 R Battino and H L Clever, The Solubthry of Gases in Liquads, Chem Rev 66, 395 (1966)

13 J P Stone et al , High-temperature Properties of Sodrum. NRL624l (Dec 24, 1964), G H Golden and I V Tokar, Thermophysical Aroperties of Sodum, ANL-7323 (Aug 1967)

14 J H Hildebrand and R $\mathrm{L}$ Scott, The Solubuliny of Nonelectrolytes, Reinhold Publıshing Corp, 3rd Ed, p 131 (J950)

I5 R Fowler and E A Guggenheım, Stanstical Thermadynamics, The University Press, Cambridge (1956)

$16 \mathrm{H} \mathrm{H}$ Uhlig, The Solubitues of Gases and Sturface Tenseon, J Phys Chem 41, 1215 (Dec 1937)

17 R A Prerottu, The Solubtity of Gases on Liquds, J Phys Chem 67, 1840 (Sept 1963)

18 H Reiss, H L Frisch, E Helfand, and J L Lebowstz, Aspects of the Starssical Thermodynamts of Red Fludds, I Chem Phys 32, II9 (Jan 1960)

19 W H Keesom, Helutm, Elsevrer, Amsterdam, p 191 (1942)

20 A M Clark, F Din, and J Robb, The Vapour Pressure 
of Argon, Physical 17,876 (Oct 1951$)$.

2I. W. G. Schnesder and J.A.H.Duffe, The Compressibility of Gases at High Temperatures. II. The Second Vinial Coefficient of Heliusm in the Temperature Range of $0^{\circ} \mathrm{C}$ to $600^{\circ} \mathrm{C}$. J. Chem. Phys. 77.751 (Sept 1949); J. L. Yntema and W. G. Schneider. The Compressibifity of Gases at High Temperatures. III. The Second Virial Coefficlent of Helium in the Temperarure Range $600^{\circ} \mathrm{C}$ to $1200^{\circ} \mathrm{C}$, ibid. 18,641 (May 1950).

22. E. Whalley, Y. Lupien, and W. G. Schneider, The Compressibultry of Gases. VII. Argon in the Tenperature Range 0 to $600^{\circ} \mathrm{C}$ and the Pressure $10-80$ Atmos. pheres. Can. J. Chem. 31, 722 (Aug 1953).
23. H. Margenau, Van der Waats Forces, Revs. Mod. Phys. $11, I$ (Jan 1939$)$.

24. G. Herzberg, Atomic Spectra and Atomic Structure, Dover Publicalions, New York, p. 200 ( 1944$).$

25. J. Bohdansky and H. E.J. Schins, Sturface Tension of the Alkali Metsts, J. lnorg. Nucl. Chem. 29, 2173 (Sept 1967).

26. JANAF Themochemical Tabies, Dow Chemical Co., Midland, Michigan (June 30, 1962).

27. P. Ascarelli, Velocity of Sound and Compressibility of Liquid Netols, Phys. Rev. 173, 271 (Sept 1968).

28 . H. C. Schnyders and H.M. Feder, Argonne National Laboratory, to be published. 